\title{
CONCEPTUAL MODEL FOR COVID 19 PROTOCOL'S EFFECT FOR INTERNAL SUPPLY CHAIN TO SUSTAIN COMPANY OPERATIONAL PERFORMANCE
}

\author{
Ermayana Megawati $^{1 *}$, Ari Heryanto ${ }^{2 *}$, Aries Susanty ${ }^{3 *}$, Novie Susanto ${ }^{3 *}$ \\ ${ }^{1}$ Industrial Engineering Department, Faculty of Engineering, Selamat Sri University \\ Kendal, Indonesian \\ Factory Manager \\ ${ }^{2}$ PT. AST Indonesia, Subsidiary of Sumitomo Forestry Corporation Japan \\ Semarang, Indonesian \\ ${ }^{3}$ Industrial Engineering Department, Faculty of Engineering, Diponegoro University \\ Semarang, Indonesian
}

\begin{abstract}
Supply chain is an organizational system in which there are roles and perform various activities, including information, funds and other resources that are interrelated in the movement of a product or service from supplier to customer. One typical supply chain management is internal supply chain management, where is one of the integrated activities that plays an important role in the operational performance of the company, but in Covid-19 pandemic era every country including PT. AST Indonesia has implemented the Covid-19 health protocols along with their government role, WHO's role also International Safety standard such as OHSA. Internal supply chain is composed strategic purchasing, production and distribution exactly will have affected by this health protocols. Some researchers have published many factors that influence the performance of the company like quality, flexibility, innovation but also important to study the relevant thing with Covid-19 health protocols. In this paper, we proposed a conceptual model consist of Covid-19 health protocols, strategic purchasing, production, and distribution to sustain company operational performance. AHP method is use in this research to find the dominant influencing protocol factor that affecting in making of ISCM sustainability strategy.
\end{abstract}

Keywords: Covid-19 health protocols; internal supply chain; company operational performance; AHP.

\section{Introduction}

The global production and supply chain system is mostly disrupted due to the coronavirus pandemic (Covid-19) since 2019. Causes by this phenomenon most of the industrial directors, managers, policymakers and engineers are searching for adequate strategies and policies for revamping supply chain and production shapes to meet consumer demand. From the global supply chain perspective in the Indonesian bonded zone area, mostly most raw materials are usually imported from overseas. In early 2020, the Covid- 19 pandemic has broken most of the transportation links and distribution mechanisms between suppliers, production facilities, and customers. Therefore, it is imperative to discuss sustainable production including internal supply chain patterns in the post-Covid-19 pandemic era. The production and supply chain operations management challenges of the pandemic situations are discussed and adequately propose the Covid-19 protocol as policy

\footnotetext{
*Penulis Korespondensi.

E-Mail: ${ }^{1}$ ermayana1802@gmail.com,

2ari_h@ast.co.id, ${ }^{3}$ ariessusanty@gmail.com,

${ }^{4}$ novie.susanto@ft.undip.ac.id
}

strategies for improving the resilience and sustainability of the system. This paper discusses the conceptual research frame, how the Covid- 19 protocol influences the internal supply chain system to sustain the Company operations.

Oliver stated in Immawan and Putri (2018) that supply chains are a physical network where companies are involved in providing raw materials, goods manufacturing, or shipping, while Supply Chain Management (SCM) is a method, tool, or management approach. In the current organization, an effective supply chain process becomes essential due to its function to ensure overall supply chain management is a success, to improve organizational performance, and to gain competitive advantage. To compete successfully, organizations are needed effective integration and collaboration of three macro processes in supply chain activities.

SCM is the backbone of a company's direction, where it integrates both material and information (Bala, 2014). SCM consists of several functions that are source, purchase, inventory management, warehouse management, operations supervision for products distribution to customers (John, 2011). SCM manages all internal and external business activities (Tian, 2009). 
Internal SCM is the whole idea of processes involved internally organizations which are planning, organizing, controlling, and coordinating in the logistics, information-flow and throughout the business process stages.

A volatile global business environment is characterized by supply chains that are increasingly longer and more intricate, with more interconnected links, higher stakeholders' expectations, and more sources of supply chain competition (Gunasekaran et al., 2001). Successful supply chain management relies on organizations working together and collaborating effectively (Lazzarini et al., 2001).

Some previous researchers explained as according, Tian (2009) the existence of internal information exchange, implementation of company strategies, and improvement of professional skills in employees are very important, so that they cannot be ignored, whereas according to, Imran and Amjad (2017) there is a significant positive relationship between logistics and performance. Then according to, Barasa et al. (2015) there is an analytical correlation revealed that there is a significant and moderate positive correlation between supply chain collaboration and the performance companies. Furthermore, according to, Hussen et al. (2017), internal integration does not always provide integration to the company and the importance of implementing supply chain integration in the industry is a source of competitive advantage through improving the company's operational performance.

\subsection{COVID- 19 Health Protocols}

Coronavirus Disease 2019 (Covid-19) is a respiratory disease caused by the SARS-CoV-2 virus. It has spread from China to many other countries around the world, including the United States. Depending on the severity of Covid-19's international impacts, outbreak conditions-including those rising to the level of a pandemic — can affect all aspects of daily life, including travel, trade, tourism, food supplies, and financial markets, to reduce the impact of Covid-19 outbreak conditions on businesses, workers, customers, and the public, it is important for all employers to plan now for Covid-19. For employers who have already planned for influenza pandemics, planning for Covid-19 may involve updating plans to address the specific exposure risks, sources of exposure, routes of transmission, and other unique characteristics of SARS-CoV-2 (i.e., compared to pandemic influenza viruses). Employers who have not prepared for pandemic events should prepare themselves and their workers as far in advance as possible of potentially worsening outbreak conditions. Lack of continuity planning can result in a cascade of failures as employers attempt to address challenges of Covid-19 with insufficient resources and workers who might not be adequately trained for jobs they may have to perform under pandemic conditions. (Guidance on Preparing Workplaces for Covid-19, OSHA 3990-03 2020).

To reduce the impact of Covid-19 outbreak conditions on businesses, workers, customers, and the public, it is important for all employers to plan now for Covid-19. For employers who have already planned for influenza pandemics, planning for Covid-19 may involve updating plans to address the specific exposure risks, sources of exposure, routes of transmission, and other unique characteristics of SARS-CoV-2 (i.e., compared to pandemic influenza viruses). Employers who have not prepared for pandemic events should prepare themselves and their workers as far in advance as possible of potentially worsening outbreak conditions. Lack of continuity planning can result in a cascade of failures as employers attempt to address challenges of Covid-19 with insufficient resources and workers who might not be adequately trained for jobs they may have to perform under pandemic conditions. OHSA set the basic steps for every employer to reduce the risk of worker exposure to SARS-CoV-2, such as

1. Develop an Infectious Disease Preparedness and Response Plan

2. Prepare to Implement Basic Infection Prevention Measures

3. Develop Policies and Procedures for Prompt Identification and Isolation of Sick People, if Appropriate

4. Develop, Implement, and Communicate about Workplace Flexibilities and Protections

5. Implement Workplace Controls

6. Engineering Controls

7. Administrative Controls

8. Safe Work Practices

9. Personal Protective Equipment (PPE)

From decree of the minister of health of the republic of Indonesia number hk.01.07/ MENKES/ 382/ 2020 concerning protocols of health for the community in places and public facilities in the control of corona virus disease 2019 (Covid-19) said that the community has an important role in breaking the chain of transmission of Covid-19, to hold new sources of transmission/ clusters in places where the movement of people, interaction between humans and large gatherings of people occurs. The community must be able to do activities again in the Covid-19 pandemic situation by adapting to new habits that are healthier, cleaner, and more obedient, which are implemented by all components in the community and empower all existing resources. The role of the community in being able to break the chain of transmission of Covid-19 (risk of contracting and transmitting) must be carried out by implementing health protocols. General health protocols must include:

1. Individual Health Protection Covid-19 transmission occurs through droplets that can infect humans by entering droplets containing the SARS-CoV-2 virus into the body through the nose, mouth, and eyes. The principle of preventing the transmission of Covid-19 to individuals is carried out by avoiding the entry of the virus through the three entrances with several measures, such as: 
a) Use personal protective equipment in the form of a mask that covers the nose and mouth to the chin, if you must leave the house or interact with other people whose health status is unknown (who might transmit Covid-19). If using a cloth mask, you should use a 3-layer cloth mask.

b) Clean hands regularly by washing hands with soap under running water or using an alcoholbased hand sanitizer. Always avoid touching your eyes, nose, and mouth with unclean hands (which may be contaminated with droplets containing the virus).

c) Maintain a minimum distance of 1 meter from other people to avoid getting droplets from people who are talking, coughing, or sneezing, and avoiding crowds, and overcrowding. If it is not possible to maintain a distance, various administrative and technical engineering can be carried out. Administrative engineering can be in the form of limiting the number of people, setting schedules, and so on. While technical engineering, among others, can be in the form of partitioning, setting entry and exit routes, and so on. Increase endurance by implementing Clean and Healthy Living Behaviors (PHBS) such as consuming balanced nutrition, physical activity at least 30 minutes a day and adequate rest (at least 7 hours) and avoiding risk factors for disease. People who have comorbidities/ comorbidities/ vulnerable conditions such as diabetes, hypertension, pulmonary disorders, heart problems, kidney disorders, immunocompromised conditions/ autoimmune diseases, pregnancy, the elderly, children, etc., should be more careful in their activities. in public places and facilities.

2. Public Health Protection of public health is an effort that must be made by all components in society to prevent and control transmission of Covid-19. The potential for transmission of Covid -19 in public places and facilities is due to movement, crowds, or interaction of people that can lead to physical contact. In protecting public health, the role of the manager, organizer, or person in charge of public places and facilities is very important to implement the following:

a. Preventive elements (prevent)

1. Health promotion activities (promote) are carried out through socialization, education, and the use of various information media to provide understanding and understanding for everyone, as well as exemplary from leaders, community leaders, and through mainstream media.

2. Protection activities, among others, are carried out by providing means of washing hands with soap that is easily accessible and meets standards or the provision of a hand sanitizer, efforts to screen the health of people who will enter public places and facilities, regulating distance guarding, disinfection of surfaces, rooms, and equipment regularly, as well as enforcing discipline on community behavior at risk of transmission and transmission of Covid-19 such as crowding not using masks, smoking in public places and facilities and so on.

b. Element of case detection (detect)

1. Facilitation in early detection to anticipate the spread of Covid-19, which can be done through coordination with local health offices or health service facilities.

2. Monitor health conditions (symptoms of fever, cough, runny nose, sore throat, and/ or shortness of breath) of all people in public places and facilities.

c. Handling elements quickly and effectively (respond).

Handling to prevent a wider spread, including coordinating with the local health office or health service facilities to carry out close contact tracing, rapid test examinations or Real Time Polymerase Chain Reaction (RT-PCR), as well as other handling as needed. The treatment for those who are sick or die in public places and facilities refers to the applicable standards in accordance with the provisions of laws and regulations.

\subsection{Component of Supply Chain Management}

The component of supply chain management according to consists of three main components, namely Turban et al. (2004).

1. Upstream Supply Chain

The upstream (upstream) supply chain includes the activities of a manufacturing company with its suppliers (which can be manufacturers, assemblers, or both) and their connections to their suppliers (second-tier suppliers). The relationship of suppliers can be extended to several strata, all roads from the origin of material (for example mine ore, plant growth). In the upstream supply chain, the main activity is procurement.

2. Internal Supply Chain

The part of the internal supply chain includes all inhouse processes used in transforming input from suppliers into the organization's output. This extends from the time of input into the organization. Within the internal supply chain, the main concern is the management of production, fabrication and inventory control.

3. Downstream supply chain

Downstream (downstream) supply chain includes all activities that involve the delivery of products to end customers. In the downstream supply chain, attention is directed to distribution, transportation warehousing and after-sale service. 


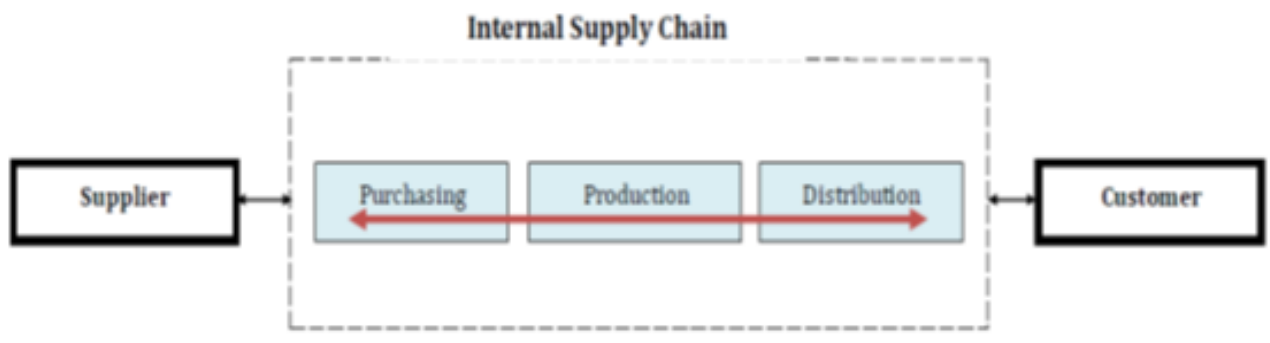

Figure 1. Typical Supply Chain, Tian (2009)

\subsection{Internal Supply Chain Management}

Measure internal/ external SCM resources and the execution of SCM reflectively. Draw support for this decision from the notions of it (Jarvis et al., 2003). Consider the direction of causality from the latent construct towards the indicators for all our constructs. This is of particular importance for our dependent construct SCM execution, given Lee et al. (2013) critique on treating formative constructs as dependent ones. Based on previous work applying those scales (Teller et al., 2011).

SCM component separated by three parts as follows, Upstream Supply Chain are the company activity that related between suppliers. Second, Internal Supply Chain are all the process that use by the organization starting from supplier to output since the material enter to the company to the distribution of the product. Third, Downstream Supply Chain, this section covered all process that involved from distribution of the product to the end user (Turban et al., 2004).

Supply Chain Management has arranged all internal and external business activity, second, relating SCM such like effective and efficient logistic management. For this reason, Internal Supply Chain Management (ISCM) define as Purchasing, production, and distribution flow, and third ISCM according for the company activity management, those are planning, organizing, control and supply chain coordinating. It is important to get the integration and supply chain coordinating (Tian, 2009).

For this reason, the notion of internal supply chain comprises of Purchasing, Production and Distribution flow, as it composed of networks of supply and demand as shown in Figure 1. The scope of this paper limited by researcher for only all off activity that collaborated with Supply Chain Management (ISCM) such as Purchasing, Production and distribution that achieved the company performance.

\subsubsection{Strategic Purchasing}

Purchasing considered as a strategic weapon that focusing on the ability to create collaborative relation for company profit (Carr \& Smeltzer, 1999). The concept of Strategic Purchasing, proactive, long-term focus, and supplier relation arranged strategically (Carr \& Smeltzer, 1999); (Carter \& Narasimhan, 1993). Suitable with previous literature, strategic planning as planning process that will guiding all the purchasing activity towards opportunity consistently with company ability to get the long-term goals.

\subsubsection{Production}

Internal supply chain conceptually divided by five dimension, therefore, supply and demand planning could show for example, in operational process where normally the planning will begin from production order schedule creation, ordered, for estimate and allocate the resources that will be use, then from the schedule, procurement activity will be held for taking decision and built the relation for customer keeping, loyalty to give the product value adding (Chopra et a., 2016).

\subsubsection{Distribution}

Distribution is defined as the transportation of the product from the point of production or transshipment to the point or points where demand has been recorded, in order to satisfy the expectations of the production enterprise and the consumer (Binioris, 2008). The physical distribution is part of the supply chain, and its purpose is to deliver goods/ services to the consumers. More specifically to the demand points of the finished product in the right place and time, in the right quantity and at the lowest possible total cost (Blanchard, 2010).

\section{Methods \\ 2.1 Research Question}

Many companies have breakdown their business in this Covid-19 pandemic era, but several companies still exist doing their business, built their trial \& error protocols to keep defense this condition, and after Indonesian government and OSHA international standard release their protocols, PT. AST Indonesia a multinational company as research object should follow this standard, and the research question are:

1. Which protocol factor are dominant influencing the decision's strategy to sustain ISCM.

2. What the effect if the influencing protocol's dominant factor not applied as important point to develop ISCM sustainability strategy

3. What the suggestion to develop ISCM sustainability strategy related with the research finding.

\subsection{Research Method}

Analytical Hierarchy Process (AHP) method will apply in this research to find and decide which dominant influencing factor are priority and important to develop the system for sustaining the ISCM of PT. AST Indonesia as research object Company. The Indicator of Covid-19 Protocol will be combined from Guidance on Preparing Workplaces for Covid-19, OSHA 3990-03 2020, and decree of the minister of health of the republic of 
Table 1. Health Protocol Indicator

\section{Health Protocol Indicator}

1. Develop an Infectious Disease Preparedness and Response Plan

2. Prepare to Implement Basic Infection Prevention Measures

3. Develop Policies and Procedures for Prompt Identification and Isolation of Sick People, if Appropriate

4. Develop, Implement, and Communicate about Workplace Flexibilities and Protections

5. Implement Workplace Controls

6. Engineering Controls

7. Administrative Controls

8. Safe Work Practices

9. Personal Protective Equipment (PPE)

(OSHA 3990-03 2020)

10. Clean hands regularly by washing hands

11. Maintain a minimum distance of 1 meter from other people to avoid getting droplets.

12. Health promotion activities

13. Protection activities

14. Element of case detection (detect)

15. Handling elements quickly and effectively (respond)

\section{(MENKES / 382/2020)}

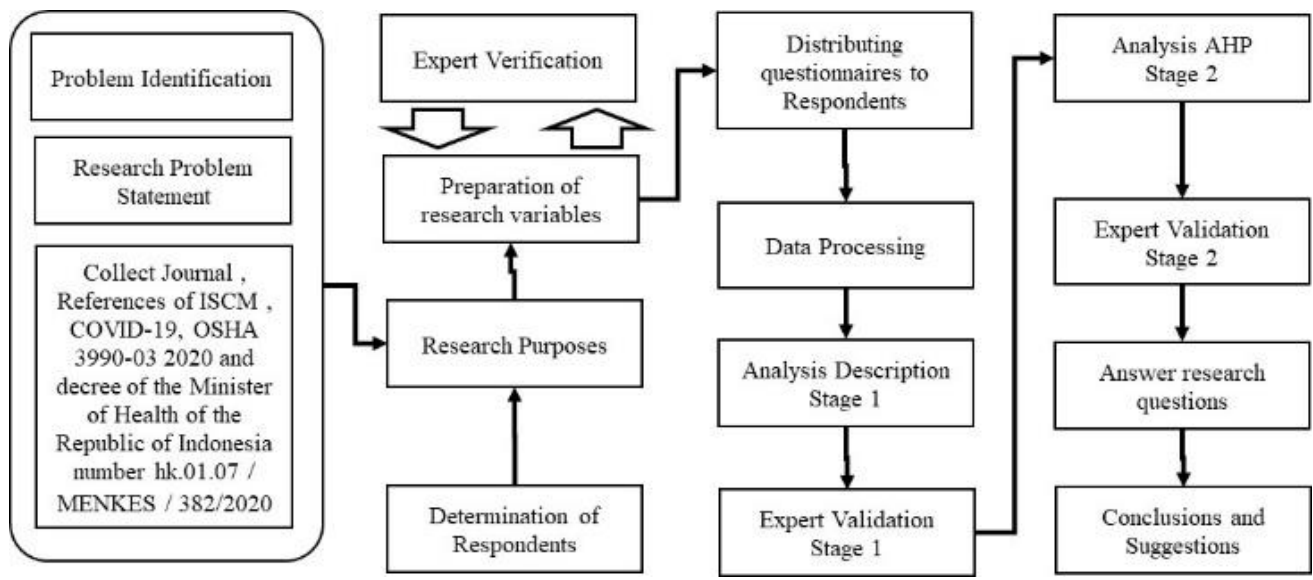

Figure 2. Conceptual Research Framework, Cristina and Eva, Imran and Amjad (2017), Hussen (2017), Hatane et al. (2018)

Indonesia number hk.01.07/ MENKES/ 382/ 2020 concerning protocols of health for the community in places and public facilities Such shown in Table 1.

OSHA health protocols standard were chosen because many multinational companies across countries applied it, while all companies in Indonesia must implement MENKES/ 382/ 2020. This research will analyze the effect of Covid-19 Health Protocol to ISCM directly and Company Operational Performance indirectly and Google form questionnaire will create and sent to the 25 respondent that related with ISCM, Company operational performance and managerial respondent. The research frame to draw up which dominant factor of Covid-19 health protocols will affect in internal supply chain such as Strategic Purchasing, Production, Distribution, and company operational performance shown in Figure 2.

\section{Discussion and Conclusion}

In the Covid-19 pandemic era, Health protocols are a priority and important to living a new normal besides Covid-19 disease, so that's why all companies need to identify the dominant factor of health protocol as the important point when consider and decide internal supply chain strategy and integration activities with many problems that arise due to lack of good coordination between the stakeholders. Researchers will decide the solution and advice, from the proposed conceptual model as in Figure 2, of course, focusing on Covid-19 health protocol dominant factor that influences ISCM strategy related to operational performance. For further research, the relationship of Covid-19 health protocols and the external Supply Chain will be sought to obtain more significant results on the Company's Operational Performance.

\section{References}

Immawan, T., \& Putri, D. K. (2018). House of Risk Approach for Assessing Supply Chain Risk Management Strategies: A Case Study in Crumb Rubber Company Ltd. In MATEC Web of Conferences, 154, 1097. EDP Sciences. 
Bala, K. (2014). Supply Chain Management: Some Issues and Challenges - A Review. International Journal of Current Engineering and Technology E-ISSN, 4(2), 946-953.

John, M. (2012). Retail Supply Chain: Challenges and Prospects.

Tian, R. (2009). Internal Logistics As A Part of Supply Chain: Case: Nokia-China, Dongguang Branch.

Jarvis, C. B., MacKenzie, S. B., \& Podsakoff, P. M. (2003). A Critical Review of Construct Indicators and Measurement Model Misspecification in Marketing And Consumer Research. Journal of Consumer Research, 30(2), 199-218.

Rigdon, E. E. (2013). Lee, Cadogan, and Chamberlain: An Excellent Point... But What About That Iceberg?. AMS Review, 3(1), 24-29.

Teller, C., Kotzab, H., \& Grant, D. B. (2012). Improving The Execution of Supply Chain Management in Organizations. International Journal of Production Economics, 140(2), 713-720.

Turban, Rainer, Porter. (2004). Supply Chain Management. http://id.wikipedia.org/wiki/ Manajemen_rantai_suplai.

Carr, A. S., \& Smeltzer, L. R. (1999). The Relationship of Strategic Purchasing to Supply Chain Management. European Journal of Purchasing \& Supply Management, 5(1), 43-51.

Carter, J., \& Narasimhan, R. (1993). Purchasing and Materials Managements Role in Total Quality Management and Customer Satisfaction (Tempe, Az: Center for Advanced Purchasing Studies).

Chopra, S., Meindl, P., \& Kalra, D. V. (2013). Supply Chain Management: Strategy, Planning, and Operation (Vol. 232). Boston, MA: Pearson.

Binioris, A. (2008). Logistics: Introduction in Supply Chain Management. Iatrikes Ekdoseis PX Passxalidis, Athens, Greece.

Blanchard, D., (2010). Supply Chain Management: Best Practices. $2^{\text {nd }}$ edition, John Wiley \& Sons, Inc., Hoboken, New Jersey.

Shobayo, P. B. (2017). Supply Chain Management and Operational Performance in Nigeria: A Panel Regression Model Approach. International Journal of Entrepreneurial Knowledge, 5(2).

Tummala, V. R., Phillips, C. L., \& Johnson, M. (2006). Assessing Supply Chain Management Success Factors: A Case Study. Supply Chain Management: An International Journal, 11(2), 179-192.

Ferdinand, A. (2014). Metode Penelitian Manajemen: Pedoman Penelitian untuk Penulisan Skripsi, Tesis, dan Disertasi Ilmu Manajemen. Semarang: Badan Penerbit Universitas Diponegoro.

Kotler, P. Keller, KL. (2007).“Manajemen Pemasaran”, Cet 2, Edisi 12, Jilid 1, Alih Bahasa: Benyamin Molan. Penerbit PT. INDEKS.

Lawson, B., Cousins, P. D., Handfield, R. B., \& Petersen, K. J. (2009). Strategic Purchasing, Supply Management Practices and Buyer Performance Improvement: An Empirical Study of UK
Manufacturing Organisations. International Journal of Production Research, 47(10), 26492667.

Pasanen, S. R. (2015). Internal Supply Chain: Process and Performance Measurement Development. Helsinki Metropolia University of Applied Sciences Master of Business Administration Business Informatics Thesis.

Banker, R. D., Potter, G., \& Schroeder, R. G. (1993). Reporting Manufacturing Performance Measures to Workers: An Empirical Study. Journal of Management Accounting Research, 5, 33.

Terziovski, M., \& Samson, D. (1999). The Link Between Total Quality Management Practice and Organisational Performance. International Journal of Quality \& Reliability Management. https://doi.org/10.1108/02656719910223728

Ramsay, J. (2001). The Resource Based Perspective, Rents, and Purchasing's Contribution to Sustainable Competitive Advantage. Journal of Supply Chain Management, 37(2), 38-47.

Carr, A. S., \& Pearson, J. N. (2002). The Impact of Purchasing and Supplier Involvement on Strategic Purchasing and Its Impact on Firm's Performance. International Journal of Operations \& Production Management, 22(9), 1032-1053.

Rossetti, C., \& Choi, T. Y. (2005). On The Dark Side of Strategic Sourcing: Experiences From The Aerospace Industry. Academy of Management Perspectives, 19(1), 46-60.

Chen, I. J., Paulraj, A., \& Lado, A. A. (2004). Strategic Purchasing, Supply Management, and Firm Performance. Journal of Operations Management, 22(5), 505-523.

Paulraj, A., Chen, I. J., \& Flynn, J. (2006). Levels of Strategic Purchasing: Impact on Supply Integration And Performance. Journal of Purchasing and Supply management, 12(3), 107122

Semuel, H., Siagian, H., \& Arnius, R. (2018). The effects of Strategic Purchasing on Organization Performance Through Negotiation Strategy and Buyer-Supplier Relationship. International Journal of Business and Society, 19 (2), 323-334.

Gimenez, C., \& Ventura, E. (2005). LogisticsProduction, Logistics-Marketing and External Integration: Their Impact on Performance. International Journal of Operations \& Production Management.

Division of Statistics and Scientific Computation. (2012). Structural Equation Modeling using AMOS: An Introduction. University of Texas at Austin.

Joseph Jr, F. (2014). Hair Jr, William C. Black, Barry J. Babin, Rolph E. Anderson.(2013). Multivariate Data Analysis.

Qadir, I., \& Ali, A. (2017). Importance of Logistics Processes for Customer Service and Firm Performance: Evidence From Furniture Industry of Pakistan. Management: Journal of Sustainable 
Business and Management Solutions in Emerging Economies, 22(3), 27-36.

Barasa, Peter Wamalwa, et al. (2015). The Impact of Supply Chain Collaboration Practice on The Performance. European Journal of Logistics Purchasing and Supply Chain Management, 3(2), 28-39

Hussen, S. O, et al. (2017). The Effect of Supply Chain Integration on Operational Performance: A Study on Chemical and Chemical Product Manufacturing Firms in Ethiopia. European
Journal of Logistics, Purchasing and Supply Chain Management, 5(2), 10-18.

Gunasekaran, A., Patel, C., \& Tirtiroglu, E. (2001). Performance Measures and Metrics in A Supply Chain Environment. International Journal of Operations \& Production Management.

Lazzarini, S., Chaddad, F., \& Cook, M. (2001). Integrating Supply Chain and Network Analyses: The Study of Netchains. Journal on Chain and Network Science, 1(1), 7-22. 